\title{
PERILAKU GUMUNAN : RASIONALITAS SEMU PEMILIH JAWA (Temuan Awal)
}

\author{
Arga Sevtyan $\mathbf{V}^{1}$ \\ Wawan Sobari ${ }^{2}$ \\ Hilmy Mochtar ${ }^{3}$ \\ Pascasarjana FISIP BKU Ilmu Politik dan Pemerintahan Universitas Brawijaya \\ Program Pascasarjana FISIP Universitas Brawijaya \\ Program Pascasarjana FISIP Universitas Brawijaya \\ Email: argasevtyan@gmail.com
}

\begin{abstract}
ABSTRAK
Perilaku pemilih pada masyarakat jawa menjadi kajian dalam artikel ini. Tujuan penelitian ini adalah memperluas kajian tentang perilaku pemilih jawa. Penelitian ini menggunakan metode penelitian kualitatif dengan pendekatan studi kasus pada Pemilukada Kabupaten Trenggalek tahun 2015. Sebelumnya sudah banyak ilmuan yang membahas tentang perilaku pemilih di Indonesia khususnya pada masyarakat jawa seperti Geertz (1960) dan Gaffar (1992). Keduanya menjelaskan perilaku memilih melalui pendekatan politik aliran dengan orientasi memilih sosio relijius dan sosio personal. Pendapat lain tentang perilaku pemilih jawa dikemukakan Sobari (2016) yang menjelaskan perilaku pemilih berdasarkan pendekatan orientasi kelompok dalam masyarakat jawa. Artikel ini mencoba melihat perilaku pemilih jawa melalui pendekatan sosio kultur pada masyarakat jawa. Pemilukada Kabupaten Trenggalek 2015 dimenangkan oleh pasangan Emil Elestianto dan Mochamad Nur Arifin sebagai penantang petahana. Masyarakat Trenggalek mayoritas adalah suku jawa yang menganut budaya mataraman dengan nilai feodalistik. Perilaku "gumunan" merupakan temuan unik dalam memperluas tentang kajian perilaku pemilih jawa. Sikap "gumunan" dalam falsafah jawa berarti mudah kagum dan heran pada kekayaan, kecerdasan, kebangsawanan orang lain. Dalam konteks Pemilukada Trenggalek perilaku pemilih "gumunan" berarti masyarakat cenderung mudah terkesan pada janji kampanye dan penampilan luar kandidat namun tidak mampu menilai apakah itu rasional atau tidak bagi kesejahteraan. Sikap "gumunan" ini dipengaruhi oleh perilaku afektif yang mencakup cara menilai sesuatu secara emosional, seperti perasaan, nilai, penghargaan, antusiasme, motivasi, dan sikap. Hal ini mejadikan rasionalitas semu pada pemilih jawa.
\end{abstract}

Kata kunci: (Perilaku Pemilih, Pemilukada, Pemilih Jawa, Falsafah Jawa, Mataraman)

ABSTRACT
The voter's behavior in Javanese society becomes a review in this article. The purpose of
this article is to expand the study of Javanese voter behavior. This research used
qualitative method using case study approach at General Election of Trenggalek Regency
in 2015. Previously there were many scientists that discussed about voter behavior in
Indonesia especially in Javanese society such as Geertz (1960) and Gaffar (1992). Both
explain the behavior of choosing through the "politik aliran" approach with the
orientation of choosing socio-religious and socio-personal. Another opinion about the
behavior of Javanese voters put forward by Sobari (2016) which explained voter behavior 
based on group orientation approach in Javanese society. This article tries to capture the behavior of Javanese voters through socio-cultural approach in Javanese society. This study was conducted on the General Election of Trenggalek in 2015 was won by Emil Elestianto and Mochamad Nur Arifin as incumbent challengers. In Trenggalek, Majority civilian is Javanese tribe who embrace the culture of mataraman with feudalistic value. The behavior of "gumunan" is a unique finding in expanding on the study of Javanese voter behavior. "Gumunan" attitudes in the philosophy of life in Javanese people means easily amazed and marveled at the wealth, intelligence, nobility of others. In the context of General Election of Trenggalek, voter behavior of "gumunan" means people tend to be easily impressed by campaign promises and outside appearance of the candidate but unable to assess whether it is rational or not for welfare. "Gumunan" was influenced by the affective behavior, including how to judge things emotionally, such as feelings, values, appreciation, enthusiasm, motivation, and attitude. This makes a pseudo rationality in Javanese voters.

Keywords: Voter Behavior, Local Election, Javanese Voters, Javanese Philosophy, Mataraman

\section{PENDAHULUAN}

Masyarakat Jawa merupakan penduduk mayoritas di Indonesia dengan jumlah mencapai 95.217.022 jiwa (Na'im, A \& Syaputra, H, 2011:89). Suku Jawa tersebar hampir di seluruh wilayah Indonesia dengan populasi terbesar ada di provinsi Jawa Tengah, Yogyakarta, dan Jawa Timur. Jumlah tersebut menjadikan suku Jawa sebagai etnis terbesar dengan presentase 40,2 persen dari seluruh penduduk Indonesia. Suku Jawa menjadi entitas politik yang dominan dalam penyelenggaraan pemilihan umum di Indonesia (Sobari, 2016).

Perdebatan teoritis tentang perilaku pemilih masyarakat Jawa sudah banyak terjadi sebelumnya. Pendekatan politik aliran yang di kemukakan oleh Geertz (1960) membagi 3 aliran dalam menjelaskan pendekatan perilaku memilih masyarakat Jawa. Dalam buku The Religion of java, Gertz menjelaskan bahwa golongan santri memiliki kecenderungan untuk memilih berdasarkan keyakinan dan memilih calon dari partai yang berideologi Islam. Golongan abangan akan cenderung memilih partai atau kandidat yang berhaluan nasionalis. Terakhir, golongan priyayi lebih memilih dengan faktor kedekatan pada elemen birokrasi (Geertz. 1960:6).

Pendekatan politik aliran Geertz (1960) merupakan fondasi awal sebagai rujukan dalam mengkaji perilaku pemilih masyarakat Jawa. Pendekatan sosio-kultur masih relevan dalam mengkaji perilaku pemilih masyarakat Jawa. Dalam penelitiannya, Gafar melanjutkan Gertz yang menyimpulkan bahwa interaksi dengan pemimpin formal mempengaruhi pilihan masyarakat pada partai pemerintah yaitu partai Golkar (Golongan Karya), Sedangkan kedekatan dengan pemimpin informal seperti ulama dan pemuka agama akan menjatuhkan pilihannya pada partai Islam yaitu PPP (Partai Persatuan 
Vol.4, No.1, April 2018

Pembangunan) (Gaffar,1992). Sejalan dengan pendapat Gertz, Asfar (1997) menjelaskan hubungan antara ketaatan beragama dengan perilaku memilih saling berkaitan. Latar belakang Islam santri cenderung memilih partai PPP. Riset yang dilakukan di Kabupaten Jombang, Jawa Timur, menunjukkan bahwa sebagian besar pemilih dari kalangan santri cenderung memilih PPP (Asfar,1997). Baik Gertz ,Gaffar, dan Asfar menekankan preferensi pemilih berdasarkan pendekatan politik aliran dengan orientasi sosiorelijius maupun sosio-personal.

Seiring dengan perkembangan politik di Indonesia, pendekatan politik aliran mulai dibantah oleh Liddle dan Munjani (2007). Dalam risetnya pada pemilu legislatif tahun 1999 dan 2004 Liddle dan Munjani menemukan bahwa orientasi religius tidak berpengaruh lagi pada perilaku memilih dalam pemilu (Liddle \& Munjani, 2007: 832-857). Temuan yang sama juga diikuti oleh berapa ilmuan lain dalam riset pada pemilu legislatif dan pemilihan presiden tahun 2009 juga menunjukkan hasil yang serupa (Mujani \& Liddle, 2010: 39). Sedikit berbeda dengan temuan Munjani dan Lieddle, hasil temuan Yustiningrum dan Ichwanuddin (2015) pada kajian pemilu tahun 2014 menyatakan ketaatan seseorang dalam beribadah tidak selalu memberikan pengaruh pada pilihan partai poltiknya. Namun, dalam pemilu ketika dihadapkan pada pilihan calon legislatif, pemilih menjadikan latar belakang agama caleg sebagai bahan pertimbangan. Pemilih akan cenderung menjatuhkan pilihan kepada calon legislatif yang menganut agama yang sama dengan dirinya. Hal ini tampak dari perolehan suara partai Islam atau partai yang memiliki basis pemilih Muslim justru mengalami kenaikan. Setidaknya ada empat partai berbasis Islam yaitu PAN, PKB, PKS, dan PPP berhasil memperoleh kursi di parlemen. Hal ini menjadikan pendekatan aliran masih relevan dalam mengkaji perilaku pemilih (Yustiningrum \& Ichwanuddin, 2015: 118-134). Namun, temuan (Liddle \& Munjani, 2010) dan (Yustiningrum \& Ichwanuddin, 2015) hanya menangkap perilaku pemilih dalam konteks pemilu nasional. Dua riset di atas belum menjelaskan karakteristik pemilih jawa secara spesifik.

Pandangan lain tentang perilaku pemilih Jawa juga dikemukakan oleh Sobari (2016) yang menjelaskan perilaku memilih berdasarkan orientasi kelompok pada masyarakat Jawa. Pemilih Jawa menyesuaikan keputusan pemungutan suara mereka berdasarkan pada pilihan terbanyak di lingkungan mereka. Hal ini didasarkan pada semangat komunal untuk hidup harmonis dan menjaga kerukunan di masyarakat (Sobari, 2016:246). Dalam penjelasannya, Sobari (2016) menggunakan istilah jawa "anut grubyug" dalam mengidentifikasi perilaku pemilih berdasarkan orientasi kelompok pada pemilukada di 3 kabupaten di jawa timur.

Dalam menganalisis perilaku pemilih ada beberapa pendekatan yang paling sering digunakan yaitu pendekatan model sosiologis atau pendekatan 
mahzab Columbia. Setiap individu didorong untuk menyesuaikan diri sehingga perilakunya dapat diterima oleh lingkungan sosialnya (Roth, 2009: 24-25). Pendekatan berikutnya adalah model psikologi atau pendekatan mahzab Michigan. Dalam pendekatan ini struktur sosial tidak berpengaruh langsung terhadap pilihan pemilih melainkan faktor-faktor jangka pendek dan jangka panjang terhadap pemilih (Roth, 2009: 37). Ada tiga aspek psikologis yang menjadi fokus kajian yaitu ikatan emosional terhadap partai politik tertentu, orientasi pemilih pada isu-isu yang berkembang dan orientasi terhadap figur kandidat (Niemi \& Weisberg, 1984: 9-12). Pendekatan selanjutnya adalah pendekatan pilihan rasional yang menggunakan pendekatan ekonomi dalam mengukur demokrasi (Roth, 2009: 38). Dalam konteks pemilu, pemilih akan menjatuhkan pilihan kepada kandidat yang dianggap mendatangkan keuntungan yang sebesar-besarnya dan menekan kerugian yang sekecilkecilnya (Lembaga Penelitian UNEJ, 2015: 17).

Artikel ini mencoba untuk memperkaya studi perilaku pemilih dalam masyarakat jawa melalui pendekatan lain. Ada kecenderungan perilaku memilih masyarakat yang dipengaruhi oleh faktor sosio-kultur mataraman yang melekat pada masyarakat di kabupaten Trenggalek. Maka, pendekatan yang digunakan dalam penelitian ini berbeda dengan model sosiologis, psikologis maupun pilihan rasional. Pendekatan yang digunakan dalam menganalisis perilaku pemilih di Kabupaten Trenggalek adalah menggunakan model Affective Intelligence. Pendekatan ini berkaitan dengan perilaku afektif seseorang mencakup cara menangani hal-hal secara emosional, seperti perasaan, nilai, penghargaan, antusiasme, motivasi, dan sikap (Bloom, 1964). Teori Affective Intelligence dikembangkan oleh Salovey dan Jack Mayer (1990). Dalam teori kecerdasan afektif, Mayer dan Salovey mencoba untuk memahami apakah ada jenis kemampuan tertentu yang memungkinkan seseorang untuk secara lebih akurat mengidentifikasi emosi pada diri sendiri dan orang lain (Marcus, 2017). Affective Intelligence dapat digunakan sebagai alternatif dalam mempelajari sikap politik, caranya adalah dengan mengidentifikasi emosi sebagai pendorong dalam menentukan preferensi kandidat dan keterlibatan isu. Selain itu juga berfungsi sebagai kekuatan yang menentukan dalam penafsiran peristiwa politik (Curran, 2008:21).

Pemilihan lokasi penelitian di Kabupaten Trenggalek karena mayoritas masyarakatnya adalah suku jawa yang secara geokultural masih mengadopsi budaya mataraman (Sutarto, 2006). Masyarakat mataraman secara umum cenderung lebih nasionalis dan abangan (Leni, 2012). Secara genealogis-geografis budaya mataraman pada mulanya tumbuh dan berkembang di wilayah kerajaan Mataram (Chalik, 2011) sehingga corak masyarakat mataraman 
Vol.4, No.1, April 2018

cenderung feodal yang masih membedakan antara golongan priyayi dengan orang biasa atau wong cilik.

Masyarakat Trenggalek sebagian besar tersebar di pedesaaan. Secara umum masyarakat trenggalek adalah masyarakat agraris yang menggantungkan perekonomiannya pada sektor pertanian. Presentase struktur perekonomian masyarakat di Kabupaten Trenggalek terbesar masih pada sektor pertanian, kehutanan, dan perikanan dengan angka 31,42\% (RPJMD Kabupaten Trenggalek, 2016). Masyarakat agraris di Kabupaten Trenggalek cenderung mengutamakan kerukunan, keharmonisan, keserasian, kegotongrongan, guyub rukun antara tetangga. Tipe masyarakat agraris juga memengaruhi pola pikir, pola sikap, dan pola perilakunya (Nurcholis, 2015: 36).

\section{METODE PENELITIAN}

Pada artikel ini ditulis berdasarkan penelitian dengan menggunakan metode kualitatif. Pemilihan metode kualitatif dipilih karena untuk memperoleh informasi mendalam tentang pengalaman sosial seseorang seperti sikap, motivasi, kepercayaan, dan perilaku dari sudut pandang orang tersebut (Polit, P.F, Beck, C.T \& Hugler, 2001). Pendekatan kualitatif dalam penelitian ini adalah menggunakan studi kasus. Pendekatan studi kasus dalam penelitian kualitatif adalah menelaah "kasus" tertentu dalam konteks atau setting kehidupan nyata kontemporer (Creswell,2014:ix). Studi kasus merupakan strategi peneltian dimana di dalamnya peneliti menyelidiki secara cermat suatu program, peristiwa, aktivitas, proses, atau sekelompok individu (Creswell,
2013:20). Pemilihan metode studi kasus dalam penelitian ini adalah karena keunikan permasalahan yang diangkat oleh peneliti yakni yang berkaitan dengan fenomena kandidat muda penantang petahana pada kontestasi Pemilukada di Kabupaten Trenggalek tahun 2015.

Pemilihan lokasi di Kabupaten Trenggalek adalah berkenaan dengan majunya pasangan kandidat EmilArifin dalam Pemilukada Kabupaten Trenggalek 2015. Kemenagan pasangan Emil-Arifin yang mencapai $76,16 \%$ dari suara total pemilih. Presentase kemenangan ini belum pernah terjadi pada Pemilukada Trenggalek sebelunya. Pengumpulan data dalam penelitian ini adalah melalui observasi dan juga wawancara mendalam pada informan. Tujuan dari observasi ini adalah untuk mengetahui secara mendalam dan menyeluruh tentang mengenai kejadian-kejadian nyata dan juga interaksi sosial yang terjadi dalam masyarakat tersebut( Berg, 2007:94). Pengambilan informan dalam penelitian ini adalah dengan teknik purpossive, yakni prosedur yang dilakukan dengan memilih informan sesuai dengan spesifikasi yang dibutuhkan dalam penelitian. Informan yang akan dipilih dalam penelitian ini adalah orang yang memiliki peran yang cukup penting dan sebagai informan kunci. Pertimbangan tersebut digunakan karena disesuaikan dengan rumusan masalah yang digunakan dalam penelitian ini. Informan dalam penelitian ini terdiri dari informan kunci dan informan biasa (Salim, 2001:125). Informan dalam penelitian ini antara lain: Konsultan Politik Calon Petahana Kholiq-Handoko (AT), Ketua Partai Politik pengusung pasangan Emil-Arifin (MH dan WK), dan beberapa masyarakat Trenggalek. 
Analisis data dalam penelitian ini terdiri dari tiga alur kegiatan yang terjadi secara bersamaan, yakni reduksi data, penyajian data, penarikan kesimpulan/verifikasi (Miles \& Huberman, 1992:16). Pada penelitian studi kasus, analsis dilakukan dengan penafsiran langsung dimana peneliti melihat suatu contoh tunggal dan menarik makna darinya tanpa mencari

\section{HASIL DAN PEMBAHASAN}

\section{Penjelasan tentang perilaku "Gumunan"}

Suku jawa adalah salah satu etnis di Indonesia yang masih kental dengan tradisi dan kebudayaan. Nilai-nilai tradisi masyarakat jawa tertuang dalam falsafah-falsafah hidup yang senantiasa dilestarikan dan dijadikan sebagai prinsip dalam kehidupan sehari-hari. Falsafah merupakan prinsip hidup yang mencerminkan spiritualitas Jawa diantaranya adalah: "rawe-rawe rantas, malang-malang tuntas" artinya jika sudah mempunyai tujuan, semua halangan dan rintangan diberantas. Hal ini menunjukkan masyarakat jawa memiliki sikap optimis. Selanjutnya "ojo adigang adigung adiguno" artinya jangan membanggakan kekuasaan, kebesaran, dan kepandaian. Prinsip ini mengajarkan bahwa manusia dilarang untuk sombong dan selalu rendah hati. "ojo gumunan lan ojo kagetan" artinya jangan terlalu terheran-heran dan terkejut pada suatu hal dengan berlebihan. Prinsip ini mengajarkan untuk selalu senatiasa mawas diri dan pandai dalam menempatkan diri pada lingkungan apapun. beragam contoh. Selanjutnya adalah menentukan setting dimana peristiwa itu berlangsung untuk menjelaskan kronologi peristiwa yang terjadi. Kemudian menentukan pola dan berusaha menemukan korespondensi antara dua atau lebih kategori. Terakhir adalah mengembangkan generalisiasi naturalistik (Creswell, 2014:277-278).

Penggunaan kata "Ojo" (jangan) adalah sebuah peringatan agar tidak melakukan suatu hal. Seperti dalam falsafah "ojo gumunan lan kagetan" berarti mengingatkan agar tidak mudah kagum dan terkejut. Karena pada kenyataannya masyarakat jawa umumnya mudah kagum dan terkesan oleh kebangsawanan, keterpelajaran, keturunan ningrat, maupun kekayaan orang lain. Orang keturunan ningrat, orang bergelar universitas dan orang berharta, di dalam masyarakat jawa yang masih feodalistik akan selalu dihormati (Harjowirogo, 1989:54).

Feodalisme dalam masyarakat jawa merupakan sebuah sikap mental terhadap sesama dengan membedakan usia atau kedudukan melalui sikap khusus (Harjowirogo, 1989: 11). Sebagai contoh masyarakat jawa akan menggunakan bahasa krama (bahasa jawa halus) kepada orang yang lebih tua atau yang memiliki kedudukan. Hal ini tampak jelas di masyarakat jawa terutama yang tinggal di pedesaan.

Warisan budaya feodal mataraman dalam masyarakat Trenggalek memengaruhi pola sikap dan perilaku yang identik dengan sikap manut (Patuh), rila (ikhlas), nerima (pasrah), dan sabar. Masyarakat di Kabupaten 
Trenggalek dalam memandang permasalahan hidup dengan cara nerima. Hal ini berakar dari filosofi hidup pada masyarakat jawa "Nrimo Ing Pandum" yang artinya menerima apa yang oleh Tuhan dibagikan kepadanya. Setiap orang mempunyai panduman-nya (pemberian) masingmasing sebagaimana ditentukan oleh Tuhan. Setiap orang harus sadar akan ukuran daripada bagian yang sudah disediakan sebagai ukuran keberhasilan dalam hidupnya (Harjowilogo, 1989: 65). Hal ini diungkapkan oleh AT salah satu informan dalam penelitian ini. angka harapan hidup Trenggalek itu tinggi karena "nerima". Bentuk dari kepasarahan hidupnya dapat dilihat dari pola pikir yang sederhana, yang penting masih bisa makan, masih bisa bekerja, masih bisa menyekolahkan anak, baru setelah itu baru memikirkan kesejahteraan (Wawancara dengan AT, 24 April 2017).

Sikap tesebut akhirnya juga memengaruhi sikap politik masyarakat Trenggalek, akibatnya adalah masyarakat tidak terlalu peduli dengan perkembangan politik dan pemerintahan. Ketika dihadapkan pada pemilukada dengan hadirnya pasangan kandidat Emil elestianto dan Mochamad Nur Arifin masyarakat menjadi gumunan (kagum) (Wawancara dengan AT, 24 April 2017). Alasannya karena pasangan kandidat ini masih muda, Emil Elestianto masih berusia 31 tahun dan Mochamad Nur Arifin berusia 25 tahun saat mencalonkan. Alasan kedua adalah faktor pendidikan dimana Emil Elestianto memiliki gelar akademik doktor dari Ritsumeikan Asia Pacific University Jepang. Selain itu prestasi Emil Elestianto juga pernah menjabat Executive Vice President dari PT Penjaminan Infrastruktur Indonesia (Persero) perusahaan BUMN kementerian keuangan dan pernah menjadi fungsionaris Nahdlatul Ulama di cabang Jepang. Alasan ketiga adalah dari status sosial keluarga dimana Emil Elestianto adalah putra dari Hermanto Dardak yang pernah menjabat sebagai Wakil Menteri Pekerjaan Umum. Selain itu juga ditunjang dengan sosok Arumi Bachsin yang seorang artis. Kemampuan finansial dari pasangan kandidat Emil-Arifin lebih tinggi dibandingkan dengan kandidat petahana dengan total mencapai Rp. 38.338.322.926.- (Tiga Puluh Delapan Milyar Tiga Ratus Tiga Puluh Delapan Juta Tiga Ratus Dua Puluh Dua Ribu Sembilan Ratus Dua Puluh Enam Rupiah) yang dilaporkan kepada KPU (KPU Kabupaten Trenggalek, 2016).

Alasan tersebut cukup membuat masyarakat Trenggalek kagum dan terkesan. Sosok Emil Elestianto dinilai cerdas, dan layak untuk memimpin Trenggalek. Masyarakat menilai dari riwayat pendidikan dan prestasi yang dimiliki Emil Elestianto (Wawancara dengan salah satu warga Desa Karangsuko Kecamatan Trenggalek, 9 Desember 2015). Faktor finansial ternyata juga menjadi penilaian warga Trenggalek, alasannya adalah karena 
Emil Elestianto adalah orang kaya (Wawancara dengan salah satu warga Desa Nglongsor Kecamatan Tugu, 9 Desember 2015). Faktor status sosial juga menjadi alasan mengapa memilih Emil Elestianto karena putra dari mantan pejabat dan cucu seorang Imam di Masjid Agung Trenggalek (Wawancara dengan salah satu warga Desa Ngantru Kecamatan Trenggalek, 9 Desember 2015).

Dari penjelasan di atas sejalan dengan sosio-kultur feodalistik mataraman yang melekat pada masyarakat di kabupaten Trenggalek. Warisan nilai feodal yang menilai seseorang dari status sosial, latar belakang pendidikan, dan kekayaan akan selalu mendapat nilai lebih di masyarakat. Hal tersebut dapat menjelaskan mengapa ada perilaku pemilih gumunan pada masyarakat jawa khususnya di Kabupaten Trenggalek.

\section{Gumunan: Dorongan Afektif atau Rasionalitas Semu Pemilih?}

Pada Pemilukada Kabupaten Trenggalek tahun 2015 menghadirkan suasana baru bagi masyarakat Trenggalek. Hadirnya pasangan kandidat muda penantang petahana yaitu Emil Elestianto dan Mochamad Nur Arifin yang kemudian berhasil mengalahkan pasangan petahana Kholiq dan Priyo Handoko. Presentase kemenganannya juga tinggi mencapai 76,16 pesen dari suara total pemilih. Adanya faktor gumunan dapat dijadikan salah satu alasan faktor yang mampu memengaruhi kemenangan pasangan ini.

Untuk menjelaskan perilaku gumunan sebagai perilaku pemilih, penelitian ini menggunakan pendekatan model Affective Intelligence. Pada pendekatan ini mengutamakan penilaian individu secara emosional, seperti perasaan, nilai, penghargaan, antusiasme, sikap, dan motivasi. Inti penghayatan hidup masyarakat jawa adalah pada sisi batiniahnya. Kebatinan merupakan salah satu perceminan atau pernyataan pandangan hidup orang jawa (Mulder, 1973). Maka, dalam melihat perilaku masyarakat jawa adalah dari sisi afektifnya. Adanya pengaruh faktor sosio-kultur mataraman yang masih kental di masyarakat Kabupaten Trenggalek akan mudah diidentifikasi melalui pendekatan ini. Budaya mataraman identik dengan sikap alus (halus), rumangsan (cenderung menilai dengan perasaan), rukun, tepa slira (berusaha menempatkan diri dalam kondisi orang lain), dan nerima (pasrah).

Perilaku gumunan pada masyarakat Trenggalek dipengaruhi oleh karakter mataraman yang feodalistik dan dorongan sisi afektifnya. Ketika dihadapkan pada pemilukada, masyarakat memberikan nilai lebih kepada sosok Emil Elestianto. Hal ini memang tampak rasional karena Emil memiliki latar belakang pendidikan dan prestasi yang bagus. Namun, apakah hal ini sudah menjadikan alasan bahwa pemilih di Kabupaten Trenggalek adalah pemilih rasional?. 
Pada kenyataannya pemilih di Trenggalek tidak benar-benar menilai secara rasional.

Pengaruh dorongan afektif menjadi dominan yang tampak dari antusiasme masyarakat ketika datang dalam kampanye pasangan Emil-Arifin. Warga sangat antusias ketika dalam kampanye tersebut dihadiri oleh Arumi Bachsin. Motivasinya hanya ingin bertemu dengan artis dan sekedar berfoto bersama (Wasono, 2015). Bagi masyarakat Trenggalek sosok Emil Elestianto menjadi luar biasa dan menjadi sesuatu yang baru sehingga masyarakat menjadi heran dan kagum (gumun).

Bagi parpol maupun tim sukses pasangan Emil-Arifin, perilaku gumunan masyarakat Trenggalek sangat menguntungkan. Parpol pengusung tidak perlu bersusah payah dalam memasarkan kandidatnya. Menurut $\mathrm{MH}$ Ibarat berjualan, pasangan Emil-Arifin ini sangat laku sekali. Kita tinggal duduk-duduk saja tidak perlu bekerja keras untuk promosi. Kalau sudah diberitahu nanti ada $\mathrm{Bu}$ Arumi masyarakat sudah berkumpul dengan sendirinya (Wawancara dengan $\mathrm{MH}, 21$ April 2017). Kehadiran Arumi Bachsin dalam setiap momen kampanye menjadi daya tarik tersendiri bagi masyarakat untuk hadir. Masyarakat Trenggalek lebih mengenal sosok Arumi Bachsin daripada Emil Elestianto (Wawacara dengan WK, 20 April 2017).
Adanya sikap nerima (pasrah) pada masyarakat Trenggalek terutama yang tinggal di pedesaaan itu seperti katak dalam tempurung yang terbatas akses dalam informasi. Masyarakat tidak banyak mencari informasi tentang politik dan lain-lain. Masyarakat hanya melihat ada artis, masih muda, pintar, dan mau peduli dengan Trenggalek dengan maju menjadi bupati. Padahal jika hanya melihat keartisannya, di luar sana banyak juga artis yang berlombalomba jadi kepala daerah (Wawancara dengan AT, 24 April 2017).

Perilaku gumunan juga mendegradasikan rasionalitas dalam memilih. Masyarakat cenderung tidak bisa menganalisa apakah itu rasional atau tidak untuk kesejahteraan. Informan mencontohkan seperti dalam materi kampanye yang disampaikan oleh pasangan Emil-Arifin banyak membuat masyarakat kagum. Dalam janji kampanye pasangan Emil-Arifin tidak akan mengambil gajinya dan akan disumbangkan ke BAZ (Badan Amil Zakat). Namun, masyarakat tidak mengetahui berapa gaji pokok bupati di Trenggalek. Masyarakat tidak menyadari bahwa ada pendapatan lain untuk bupati di luar gaji pokoknnya yang justru nominalnya lebih besar (Wawancara dengan AT, 24 April 2017).

Masyarakat Trenggalek tidak bisa menilai suatu janji kampanye secara rasional. Sebagai contoh adalah janji kampanye pasangan Emil-Arifin yang akan mendatangkan investor. kemudian masyarakat hanya mampu 
menilai jika pasangan Emil-Arifin jadi bupati banyak investor datang sehingga lapangan kerja banyak. Namun, masyarakat tidak menyadari bahwa letak geografis dan kondisi topografis di Kabupaten Trenggalek tidak mendukung untuk masuknya investasi. AT mencontohkan investasi untuk membuat pabrik garmen di Trenggalek. Tapi ketika produk itu jadi dan akan dibawa ke tempat pemasarannya untuk dijual, Trenggalek itu jauh dari pusat perdagangan dan transportasi. Jika dikalkulasikan biaya transportasi dari Trenggalek ke Surabaya misalnya, akan menjadi jadi lebih besar. Tentu akan sulit bagi investor untuk masuk ke Trenggalek. hal-hal seperti inilah yang tidak mampu dianalisa dengan baik oleh masyarakat Trenggalek (Wawancara dengan AT, 24 April 2017).

Perilaku memilih masyarakat yang gumunan juga di pengaruhi oleh faktor pendidikan politik yang masih rendah dan pemilih rasional yang masih sedikit jumlahnya. Kesadaran dan pemahaman akan hak dan kewajiban sebagai pemilih masih rendah. Masyarakat sudah terbiasa dengan pola kampanye dengan model money politic (Wawancara dengan AT, 24 April 2017).

Perilaku gumunan dalam memengaruhi perilaku memilih masyarakat di Kabupaten Trenggalek merupakan rasionalitas semu pemilih. Pengaruh sosio-kultur mataraman yang masih feodalistik dengan kesadaran politik yang rendah menjadikan masyarakat cenderung menilai kandidat dari sisi afektif. Gumunan juga menjadikan masyarakat mudah terkesan hanya dengan melihat dari penampilan luar kandidat dan tidak mampu menganalisa isu politik secara rasional. Masyarakat Trenggalek cenderung mudah kagum pada hal-hal baru.

\section{KESIMPULAN}

Perilaku gumunan pada masyarakat Trenggalek merupakan bentuk dorongan afektif dalam menilai seorang kandidat. Faktor afektif dapat dijadikan alternatif alasan yang mendorong seseorang dalam menentukan preferensi kandidat. Hal tersebut dikarenakan kultur feodalistik masyarakat jawa yang lebih menggunakan perasaaan dalam menilai suatu hal. Termasuk dalam konteks memilih dalam pemilukada, kesadaran afektif yang dipengaruhi sosio-kultur jawa mataraman yang identik dengan sikap alus (halus), rumangsan (cenderung menilai dengan perasaan), rukun, tepa slira (berusaha menempatkan diri dalam kondisi orang lain), dan nerima (pasrah) menjadikan perilaku gumunan dapat dijadikan variabel baru dalam melihat perilaku pemilih jawa.

Faktor perilaku gumunan juga telah mendegradasikan rasionalitas dalam memilih. Akibatnya rasionalitas yang tampak hanya rasionalitas semu. masyarakat cenderung mudah terkesan hanya dengan melihat hal yang tampak dari kandidat seperti gelar akademik, 
latar belakang pekerjaan, status sosial, dan kekayaan. Selain itu, perilaku gumunan juga dipengaruhi oleh faktor pendidikan politik yang masih rendah dan pemilih rasional yang masih sedikit jumlahnya.

\section{DAFTAR PUSTAKA \\ Buku}

Creswell, W. J, (2014). Penelitian Kualitatif \& Desain Riset. Yogyakarta: Pustaka Pelajar.

Creswell, W.J, (2013). Research Design: Pendekatan Kualitatif, Kuantitatif, dan Mixed. Yogyakarta: Pustaka Pelajar.

Berg, B. L, (2007). Qualitative Research Methods for The Social Sciences. Boston: Pearson Education, Inc.

Bloom B., B. Mesia, and D. Krathwohl (1964). Taxonomy of Educational Objectives (two vols: The Affective Domain \& The Cognitive Domain). New York. David McKay.

Gaffar, Afan, (1992). Javanese Voters: A Case Study of Election under a Hegemonic Party System. Yogyakarta: Gadjah Mada University Press.

Geertz, Clifford, (1960). The Religion of Java. London: Free Press of Glencoe.
Hardjowirogo, Marbangun , (1989). Manusia Jawa. Jakarta: CV. Haji Masagung

Miles \& Huberman, 1992, Analisis Data Kualitatif: Buku Sumber Tentang Metode-Metode Baru/Matthew B. Miles, A. Michael Huberman. Terj. Tjetjep Rohendi Rohidi. Jakarta: UI Press.

Mulder, Niels, (1973). Kepribadian Jawa dan Pembangunan Nasional, Gadjah Mada University Press, Yogyakarta.

Nurcholis, (2015). Fenomena Perilaku Sosial Pemilih Pada Pilpres Tahun 2014 Di Kabupaten Trenggalek. Laporan Penelitian. KPU Kabupaten Trenggalek.

Niemi, R. G., \& Weisberg, H. F. (1984). Controversies in voting behavior $2^{\text {nd }}$. Washington DC: CQ Press.

Roth, Dieter, (2009). Studi Pemilu Empiris: Sumber, Teori-teori, Instrumen dan Metode. Jakarta: Lembaga Survei Indonesia.

Salim, A, (2001). Teori dan Paradigma Penelitian Sosial (Pemikiran Norman K. Denzin, dan Egon Guba, serta Penerapannya). Yogyakarta: Tiara Wacana.

(2016) Dokumen RPJMD Kabupaten Trenggalek 2016-2021. 
Na'im, A \& Syaputra, H (2011). Kewarganegaraan, suku bangsa,agama dan bahasa seharihari penduduk Indonesia: Hasil sensus penduduk 2010. Jakarta: Badan Pusat Statistik.

Polit, P.F, Beck, C.T \& Hugler (2001). Essential of Nursing Reaserch: Methods Appraisal and utilization. Philadelpia: J.B Lippincott.

\section{Jurnal}

Asfar, Muhammad (1997). Pergeseran Otoritas Kepemimpinan Kiai. Jurnal Ilmu Politik, No.17, tahun 1997.

Chalik, Abdul, (2011). Islam Mataraman dan Orientasi Politiknya Dalam Sejarah Pemilu di Indonesia. ISLAMICA, Vol. 5, No. 2, Maret 2011: 269-277

Curran, Michael. D (2008). Affective Intelligence, The Political Persuasion Process, And Outcome Intent: An Experimental Test. The University of Arizona. Dissertation

Leni, Nurhasanah (2012). Demokrasi Dan Budaya Politik Lokal di Jawa Timur Menurut R. Zuhro, Dkk. Jurnal TAPIs Vol.8 No.1 Januari - Juni 2012: 20-39.

Liddle, R. William \& Mujani, Saiful (2007). Leadership, Party, and Religion: Explaining Voting Behavior in Indonesia. Comparative Political Studies 40(7): 832-857.
Mujani, Saiful \& Liddle, R. William (2010). Personalities, Parties and Voters. Journal of Democracy 21(2): 35-49.

Sobari, Wawan, (2016). Anut Grubyuk in the Voting Process: The Neglected Explanation of Javanese Voters. Southeast Asian Studies, Vol. 5, No. 2, August 2016 : 239-268

Yustiningrum, RR. E \& Ichwanuddin, Wawan (2015). Partisipasi Politik dan Perilaku Memilih Pada Pemilu 2014. Jurnal Penelitian Politik LIPI, Volume 12, No. 1 Juni 2015 : 117-135

\section{Artikel Online}

Marcus, George E. (2017). How Affective Intelligence Theory Can Help Us Understand Politics. Diakses pada 4 Februari 2018, dari http://emotionresearcher.com/how -affective-intelligence-theory-canhelp-us-understand-politics/

Sutarto, Ayu (2006). 10 Pembagian Wilayah Jawa Timur. Diakses pada 4 Februari 2018. Dari: http://digilib.its.ac.id/ public/ITSUndergraduate-14190-chapter1pdf.pdf.

Wasono, Hari. T. (2015). Tempo edisi Senin, 19 Oktober 2015. Dari: https://nasional.tempo.co/read/71 1003/suami-arumi-bachsinpopuler-pesaing-ragukan-hasil- 
Vol.4, No.1, April 2018

survei. diakses pada 20 Desember

2017. Pukul 20.00 WIB 